\title{
FEDERALISMO, FRAGILIDADE FINANCEIRA E OS DESAFIOS CONJUNTURAIS PARA A ECONOMIA DO RIO GRANDE DO NORTE
}

Caio Cezar Fernandes da Silva ${ }^{1}$ William Eufrásio Nunes Pereira ${ }^{2}$

RESUMO: O presente artigo busca abordar os aspectos estruturais sob os quais o espaço econômico do Rio Grande do Norte adentra na nova conjuntura de crise, especialmente no que tange aos problemas e limitações de ação do governo estadual. Em primeiro lugar, foi demonstrado que que se acumulam elementos regressivos historicamente, e após um período de crescimento considerável, as novas crises possuem alto potencial destrutivo dos ganhos econômicos auferidos. Em segundo lugar, o contexto federativo e os problemas das instituições de estado local, materializados na questão financeira, engessam a possibilidade de iniciativas locais para combater a crise. Concluímos que sem a intervenção e coordenação do Estado Nacional de forma efetiva não será possível visualizar um horizonte diferente se não o de crise generalizada.

Palavras-Chave: Crise; Estado; Rio Grande do Norte.

\section{FEDERALISM, FINANCIAL FRAGILITY AND THE ECONOMIC CHALLENGES FOR THE ECONOMY OF RIO GRANDE DO NORTE}

\begin{abstract}
This article seeks to address the structural aspects under which the economic space of Rio Grande do Norte enters the new crisis scenario, especially with regard to the state government issue. First, it has been shown that historically regressive elements accumulate, and after a period of considerable growth the new crises have high destructive potential of the economic gains earned. Secondly, the federative context and the problems of local state institutions, materialized in the financial issue, cast the possibility of local initiatives to combat the crisis. We conclude that without the intervention and coordination of the National State effectively it will not be possible to visualize a different horizon if not that of a generalized crisis.
\end{abstract}

Keywords: Crisis; State; Rio Grande do Norte.

\footnotetext{
${ }^{1}$ Economista e mestrando em economia regional pela Universidade Federal do Rio Grande do Norte. E-mail: ccezarfernandes@gmail.com

${ }^{2}$ Economista, Doutor em Ciências Sociais. Professor do Departamento d Economia e do Programa de Pós-Graduação em Economia na Universidade Federal do Rio Grande do Norte -UFRN. E-mail: willa@ufrnet.br
} 


\section{INTRODUÇÃO}

Dentre os elementos constitutivos de um Estado-Nação, as relações de economia política dos consumidores, produtores e do Estado no território desempenham um papel fundamental na constituição da coesão e cooperação mútua para o desenvolvimento econômico, social e tecnológico. Favorecer os meios para integração da economia nacional de forma a proporcionar o crescimento econômico homogêneo e a distribuição pessoal e espacial da renda é, por conseguinte, fomentar a Federação. Surge assim um conceito de pacto federativo como uma aliança de economia política, cujos valores axiológicos, seguindo a argumentação de Mendes (2015), devem se assentar sobre o princípio democrático e na correspondência e harmonia entre a autonomia local e a soberania do Estado União.

A questão da redistribuição ótima do poder político e da capacidade de intervenção econômica, através do território, encontra como seu principal desafio a questão das desigualdades regionais. No Brasil, com suas dimensões continentais, as profundas desigualdades estruturais colocam em contraste os espaços regionais dos entes federados (estados e municípios) em múltiplas e sobrepostas relações de centro-periferia.

Nesse contexto, a ação das políticas de desenvolvimento econômico e social, tidas para Bresser-Pereira (2017) como o objetivo último do Estado Nacional, tem como campo de trabalho a busca pela coordenação das diferentes trajetórias históricas de desenvolvimento em uma trajetória nacional harmônica e progressiva. Essa harmonia regional se expressa através da busca pelos fundamentos econômicos do federalismo que, em primeiro lugar, se dão na convergência de níveis de emprego e renda através da coesão das geografias de produção e trabalho entre as esferas subnacionais.

Conforme a Constituição Federal de 1988, através do artigo 170, é atributo da União a redução das desigualdades regionais e sociais e torna pétreo, através do artigo 60, o formato federativo do Estado-Nação brasileiro. No entanto, não se deve desconsiderar o papel dos entes federados na busca pelo desenvolvimento, tanto pela demarcação de suas atribuições (na educação, saúde, segurança pública e etc.) diretamente engajadas na pretensão de desenvolvimento, quanto pela necessidade 
de um processo de decisão político democrático que perpasse todas as esferas de governança da federação, vertical e horizontalmente.

Como demonstrado por Pereira (2018), a questão fiscal é o aspecto central que define a capacidade de os entes federados empreenderem seus papeis constitucionais na efetivação do pacto federativo. É possível compreender a importância do papel estrutural das políticas públicas estaduais a partir do quadro de ausências e insuficiências destas, comparando-as a um contexto no qual os estados com contam com disponibilidade fiscal e financeira e o planejamento adequado que os permita ter capacidade de promover investimentos significativos em proporção de suas receitas correntes, acima da taxa de depreciação do patrimônio público.

A questão fiscal em tempos de pandemia perpassa por duas dimensões. A primeira urgente, emergente e essencial, que consiste no aumento dos gastos para 0 controle e combate a pandemia e a segunda pela necessidade de ampliação dos recursos para a efetivação dos gastos necessários tanto a epidemia, quanto aos investimentos necessários para o combate a recessão que afeta a economia. As duas dimensões estão intrinsicamente interligadas.

\section{O RIO GRANDE DO NORTE NO FEDERALISMO BRASILEIRO: ELEMENTOS DO SUBDESENVOLVIMENTO E SUA RELAÇÃO COM AS INSTITUIÇÕES DE ESTADO}

Não é tarefa trivial pensar o estado do Rio Grande do Norte em sua trajetória histórica no contexto do lugar que ocupa no espaço federativo do Brasil. Contudo, alguns enunciados e visibilidades da estrutura econômica e política do estado nos fornecem os elementos históricos fundamentais para compreender a forma de articulação institucional em que se coloca o estado atualmente. Em primeiro lugar, é necessário visualizar o espaço geográfico potiguar, em todas as suas dimensões, enquanto periferia do capitalismo brasileiro, e, em segundo lugar, as características de nosso subdesenvolvimento.

Conforme denota Araújo (2009), o povoamento e o processo de formação econômica do atual território do estado se deram longe dos espaços que engendraram processos virtuosos de crescimento e desenvolvimento no país. Os ciclos econômicos que obtiveram sucesso no Nordeste do Brasil e permearam as fronteiras do estado não foram capazes de criar encadeamentos significativos, ou ainda obter escala como 
ocorreu no Centro-Sul do país e em menor hierarquia, dentro do Nordeste, na Bahia e Pernambuco.

A leitura de Faoro (2001), Furtado (1977) e Prado Júnior (1963) mostra que uma vez organizados a estrutura econômica do Brasil em conjunto com os instrumentos de Estado se estabeleceu também a demarcação originária dos espaços periféricos. Assim, remetendo o argumento a Lefebvre (2016) e Raffestin (1993), o exercício do poder econômico pelas classes que o detinham, por sua vez, determinou a organização e a capacidade de intervenção das esferas territoriais do Estado.

No Rio Grande do Norte, foi somente no início do século XIX que se pode falar em estruturação jurídica e política do Estado, bem como de uma vida econômica em escala significativa, pela via da produção de açúcar. Como mostram Trindade (2010) e Lindoso (1992), em decorrência da demonstração de poder político na revolução liberal de 1817, articulada no estado pela aristocracia dos Albuquerque Maranhão, as instituições locais foram dotadas com maior autonomia política, jurídica e fiscal.

É dessa forma que, definidas as fronteiras políticas, o Rio Grande do Norte se insere no formato federativo. O nascimento da esfera de poder público local, no entanto, em nada teve relação com o enunciado "objetivo moderno do Estado" democrático, ou seja, com a promoção do desenvolvimento econômico e social. Monteiro (2007) e Trindade (2010), fornecem os elementos para compreensão de que foram criadas as garantias, a partir de poderes legais, inclusive o poder de polícia, para a reprodução do processo de concentração fundiária, o controle pleno de propriedade sobre os fatores de produção, e de reprodução, através de gerações, de uma força de trabalho marginalizada e pobre. O clientelismo das oligarquias, seguindo Lindoso (1992), portanto, marca o processo de inserção do espaço político do estado no federalismo brasileiro.

Ao longo dos séculos XIX e XX, a falência das culturas da cana de açúcar e do algodão, que sustentaram o processo de acumulação local, aliada a incapacidade de promoverem um salto qualitativo na estrutura produtiva ${ }^{3}$, deslocaram e atrelaram historicamente o lócus de poder econômico univocamente ao controle dos instrumentos locais de Estado. Assim, as restruturações produtivas, por

${ }^{3}$ Movimento registrado e explicado por Araújo (2009). 
condicionantes internos e externos, carregaram sempre o clientelismo como um elemento de alto potencial regressivo.

É cara à compreensão do lugar do Rio Grande do Norte na federação brasileira visualizar a organização política do território e exercício do poder calcados sobre a manutenção da ordem sistêmica que surgiu no plano das instituições do subdesenvolvimento. $O$ enunciado basal que se pode obter, a partir das visibilidades históricas, está no fato de que o exercício do poder local sempre atuou de forma regressiva através do tempo. Independentemente das transformações radicais no formato constituinte da federação, entre pactos centralizadores autoritários, como o foi na primeira república, era Vargas e na ditadura militar, até as tentativas de descentralização, especialmente com a Constituição Cidadã de 1988 (TINOCO, 2018).

Até a segunda metade do século XX, sobretudo nos anos 1970, as reverberações do que Cano (1985) denominou como processo de "desconcentração virtuosa" do capital produtivo se estabelece no território do Rio Grande do Norte. Esse processo foi baseado em duas grandes políticas, em primeiro lugar pela ação dos benefícios advindos da Superintendência para o Desenvolvimento do Nordeste (SUDENE), a partir de sua fundação em 1959, em segundo lugar ao segundo Plano Nacional de Desenvolvimento (II PND), em um contexto de amplo crescimento econômico, instalado no pós-guerra.

A industrialização, apesar de ter obtido relativo sucesso promovendo crescimento econômico e grandes transformações no tecido urbano do estado, foi marcada por limitações. Incapazes de promover a redução das desigualdades e elevar o padrão de vida da população, como era sua pretensão original, as políticas de desenvolvimento possuíam duas características essenciais para explicar a natureza de suas falhas. Sob a tutela do pacto de poder do regime militar, os projetos atendidos foram substancialmente concentrados na Bahia, Pernambuco e Ceará, o que fortaleceu o status precedente das desigualdades em que o Rio Grande do Norte se coloca enquanto periferia. Outra característica é da natureza dos fluxos de investimento, que se concentraram na indústria tradicional, cujas raízes já despontavam no parque industrial do estado retidas nas proximidades dos espaços urbanos (ARAÚJO, 2009).

Essa questão requer uma análise mais profunda, pois dela se enuncia que um dos objetivos da ação local das políticas seria integrar a produção de algodão à 
indústria, o que não ocorreu devido a falência da cultura. Além disso, a propriedade do capital industrial que se desenvolveu no estado não foi endógena às suas fronteiras e, portanto, o fluxo induzido de investimentos levou a uma alteração do padrão de concorrência do mercado cuja consequência foi a bancarrota de pequenos e médios produtores locais (ARAÚJJO, 2009).

Assim, o quadro que se desenhou no final dos anos 1970 aponta para o Estado, que representou a visualização de uma estrutura econômica frágil, sem relações setoriais significativas, apresentando graves e irresolúveis questões sociais. Com poder institucional de intervenção reduzido, restou a organização local do Estado acompanhar as transformações que vinham sendo traçadas pela União. Para a velha elite, em especial a parcela que não conseguiu se articular com o patrimonialismo na política nacional, restou a perda de parte do seu protagonismo devido a troca do centro orgânico de acumulação capitalista, partindo do setor primário para a predominância da indústria, do comércio e serviços (SILVA, 2008).

Surge na conjuntura econômica a crise da dívida dos anos 1980, conjuntamente ao alcance dos limites do processo de concentração de renda e níveis de pobreza, avançando ao longo da década com impacto regressivo que cessou somente com a passagem do milênio. Esse cenário trouxe de positivo, do ponto de vista político e institucional, o processo de redemocratização e a constituição de 1988, assim como a reestruturação da federação com a garantia de maior autonomia as unidades federadas. Por outro lado, o discurso político dominante colocou em prática uma ampla reforma do Estado e de seu padrão de intervenção na economia, de forma que as políticas regionais foram extintas (SILVA, 2008).

Do ponto de vista regional, o impacto recessivo conduziu um amplo processo de fragmentação da Nação, em que os interesses e os padrões de crescimento sem um modelo nacional de acumulação que tivesse sustentação nos componentes de demanda agregada, ou na expansão da estrutura produtiva, levaram a um ambiente de crescentes disputas dentro do território brasileiro. A abertura da economia e a crise abalou as estruturas industriais e levou a falência de cadeias de produção reconduzindo a economia para a especialização na produção de primários (PACHECO, 1996).

Para os espaços periféricos essa dinâmica quando não regressiva, foi amplamente promotora de estagnação transformando o horizonte econômico. O papel 
do Rio Grande do Norte nas disputas que se seguiram pela alocação espúria de investimentos via guerra fiscal, foi em grande parte marginal e defensivo. Dada a alta mobilidade do capital produtivo das indústrias tradicionais e o poder político assimétrico da grande indústria, se tornou imperativo criar benefícios fiscais em proporção iguais ou maiores as àquelas oferecidas por outros Estados, sem, contudo, conseguir atrair investimentos, vistos os imensos gaps de infraestrutura básica para a produção.

Se desenhou, dessa forma, um intrincado modelo de instituições de Estado local, limitadas por diversos aspectos conjunturais de crise, que sobrevieram sobre os problemas estruturais e os transformaram adicionando novos elementos regressivos. A baixa capacidade e campo de atuação do Estado se confrontam, de forma contraditória, à sua ampla importância dentro da economia do Rio Grande do Norte. O somatório dos fracassos históricos na tentativa de criar diferenças entre a repetição contínua dos problemas seculares do subdesenvolvimento, resultou no status quo de anomia do Estado, incapaz de garantir endogenamente suas obrigações constitucionais e longe de ser capaz de qualquer efetivação de papel no desenvolvimento econômico (SILVA, 2019).

\section{UM RETRATO DA ECONOMIA DO RIO GRANDE DO NORTE: EXPANSÃO E DECLÍNIO NO PRIMEIRO QUINTO DE SÉCULO}

Uma característica da economia do Rio Grande do Norte enquanto periferia, distante dos mercados centrais do país espacialmente e qualitativamente, é o baixo nível de atividade econômica e, consequentemente, elevada volatilidade do produto agregado. No período de ascensão do ciclo econômico, de 2004 a 2014, o crescimento acumulado foi contínuo, apresentando oscilação com os efeitos da crise financeira internacional de 2008/2009 e desacelerando após 2010, enquanto no Rio Grande do Norte o desaceleramento se evidencia a partir de 2011 (SILVA, 2019).

O movimento de quebra da tendência de crescimento ocorre em 2014. O setor industrial foi o primeiro a ser atingido pela desaceleração, em termos de produto e emprego, porém, foi a quebra da dinâmica do setor de comércio e serviços que deu a direção para a recessão de 2015 e 2016. O terciário tem o maior peso cíclico na economia local determinando em primeiro plano as variações de produto, e, guiando uma queda de $8,56 \%$ no nível de produto em dois anos (SILVA, 2019). 
Gráficos 1, 2 e 3- Variação ano-a-ano e acumulada do PIB e variação acumulada do PIB per capita no Brasil, Nordeste e Rio Grande do Norte (\%)

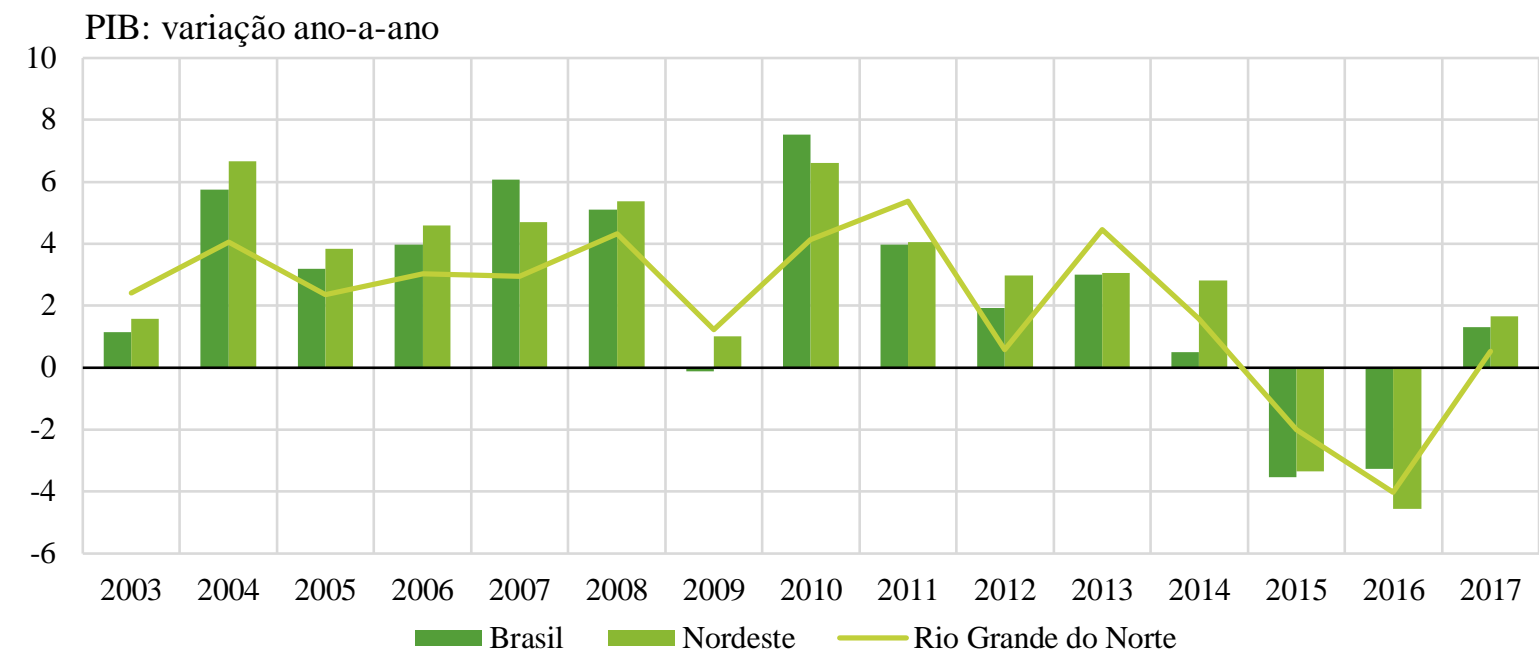

PIB: Número índice, $2002=100$
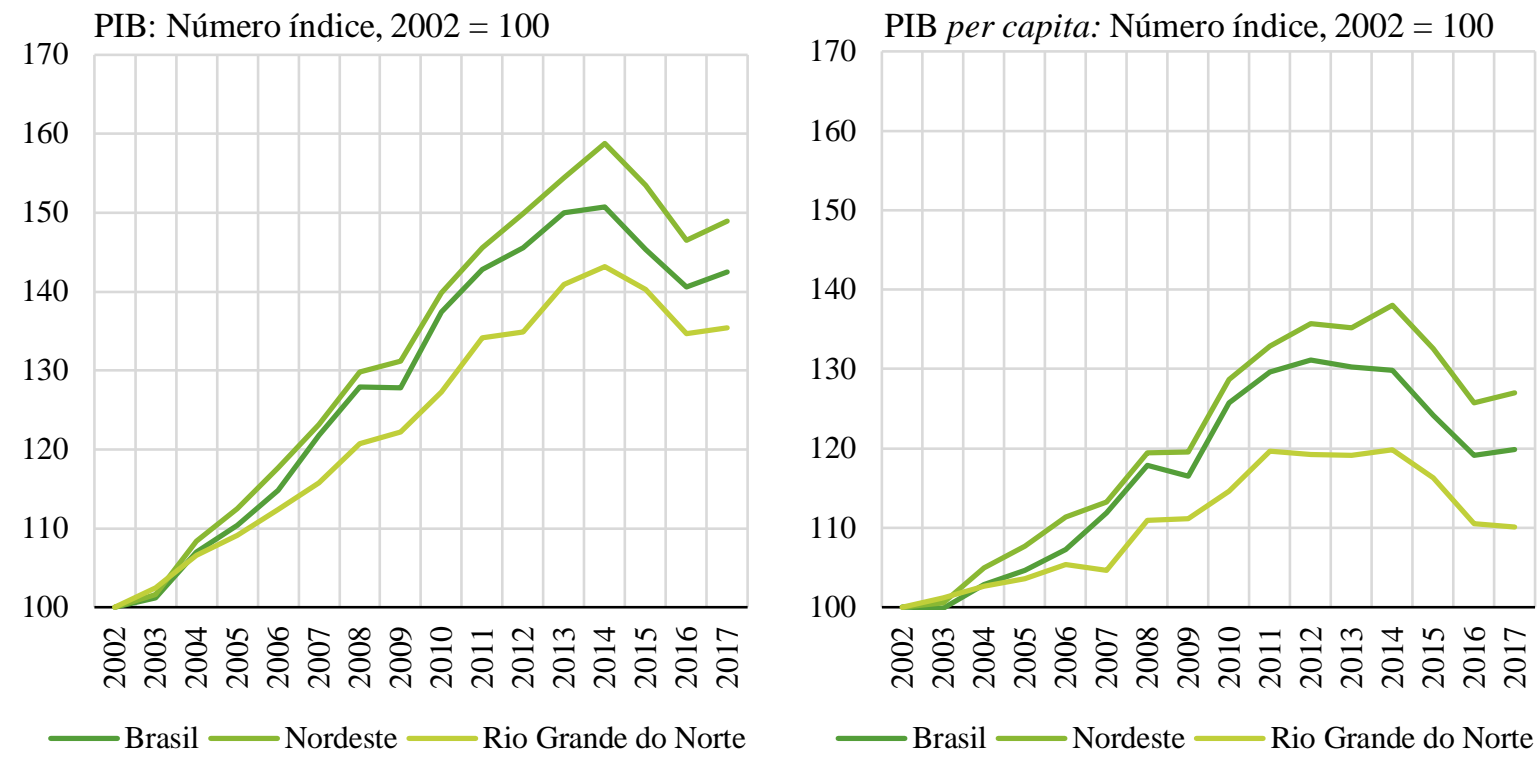

Fonte: Elaboração própria com base em dados do SCR/IBGE. Nota: Série especial encadeada. Para efeitos de cálculo de PIB per capita foi utilizada a estimativa de população oficial do IBGE, exceto para os anos de 2010, onde foi utilizado o dado do CENSO, e 2007, onde foi utilizada a estimativa da PNAD contínua.

O estado nas décadas finais do século XX apresentava taxas de crescimento superiores as taxas de crescimento nacional e da região Nordeste, nada obstante, após a estabilização monetária da economia a consolidação e estabilização relativa da escala econômica fizeram as taxas de crescimento convergirem, sem, no entanto, ter corrigido a heterogeneidade secular entre os espaços econômicos (ARAÚJO, 2009; SILVA, 2008).

No início da década de 2000, a dinâmica dos espaços supralocais passou a ser maior. A média de crescimento do país no período de 2004 a 2014 foi de 3,39\%, no 
Nordeste essa taxa foi de 3,67\% e no Rio Grande do Norte de 3,2\%. A dinamicidade relativa inferior à da economia ocorreu em 8 dos 11 anos de expansão do mercado interno e crescimento econômico, sendo um indicativo estrutural da incapacidade de a economia crescer a taxas que a permita alcançar o patamar da estrutura econômica e produtividade na contramão de outras economias do Nordeste (SILVA, 2019).

Gráfico 4 - Participação do Rio Grande do Norte no Produto Interno Bruto do Nordeste e Brasil (eixo secundário)

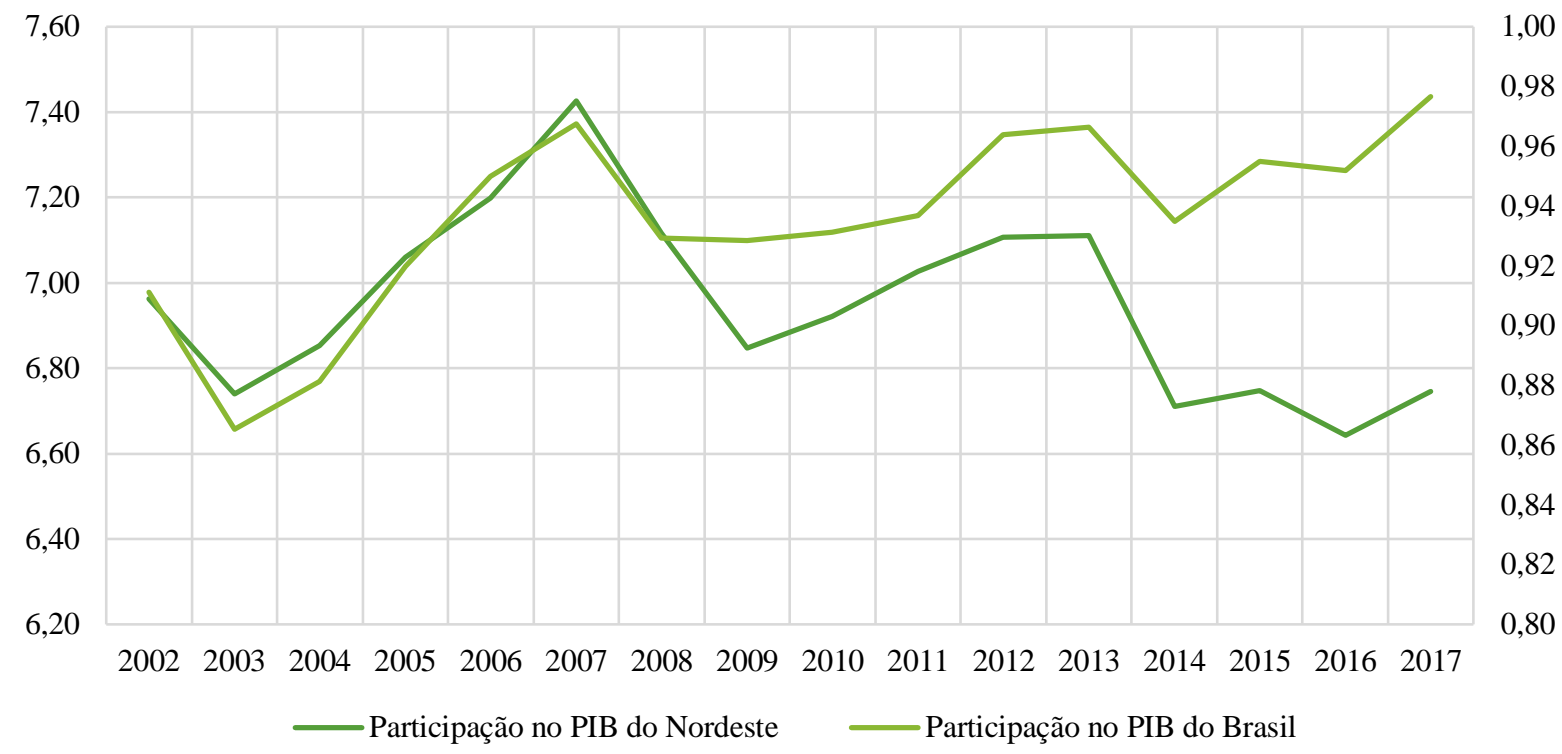

Fonte: Elaboração própria com base em dados do SIDRA/IBGE.

Simultânea à oscilação de crescimento, a importância hierárquica do espaço econômico do Rio Grande do Norte dentro do território do país também variou, positivamente ascendente até 2007 tanto em âmbito regional quanto nacional ${ }^{4}$, e tomando trajetórias diferenciadas a partir de 2009. O estado cresceu em referência ao produto nacional, não por dinamicidade endógena, mas a partir do elemento espúrio da crise e estagnação dos espaços centrais, assumindo tendência de queda em relação ao Nordeste (SILVA, 2019).

Uma característica do espaço econômico do estado enquanto periferia é a baixa extensão do mercado privado em relação aos espaços centrais, e como consequência desse fenômeno a participação do fundo público enquanto componente orgânico do fluxo circular ganha significativa importância frente ao setor privado. A participação da administração pública na formação do valor agregado é superior as

\footnotetext{
${ }^{4}$ Do ponto de vista na escala da economia nacional foi uma evolução desprezível, apesar de ser significativa em termos locais.
} 
taxas nacionais e regionais, constituindo o segundo em termos de importância relativa (a partir de 2014), superado somente pelo terciário.

Gráficos 5 e 6 - Participação do setor público no valor agregado do Brasil, Nordeste e Rio Grande do Norte, variação anual do valor agregado pelo setor público e composição na taxa de crescimento do PIB (\%)
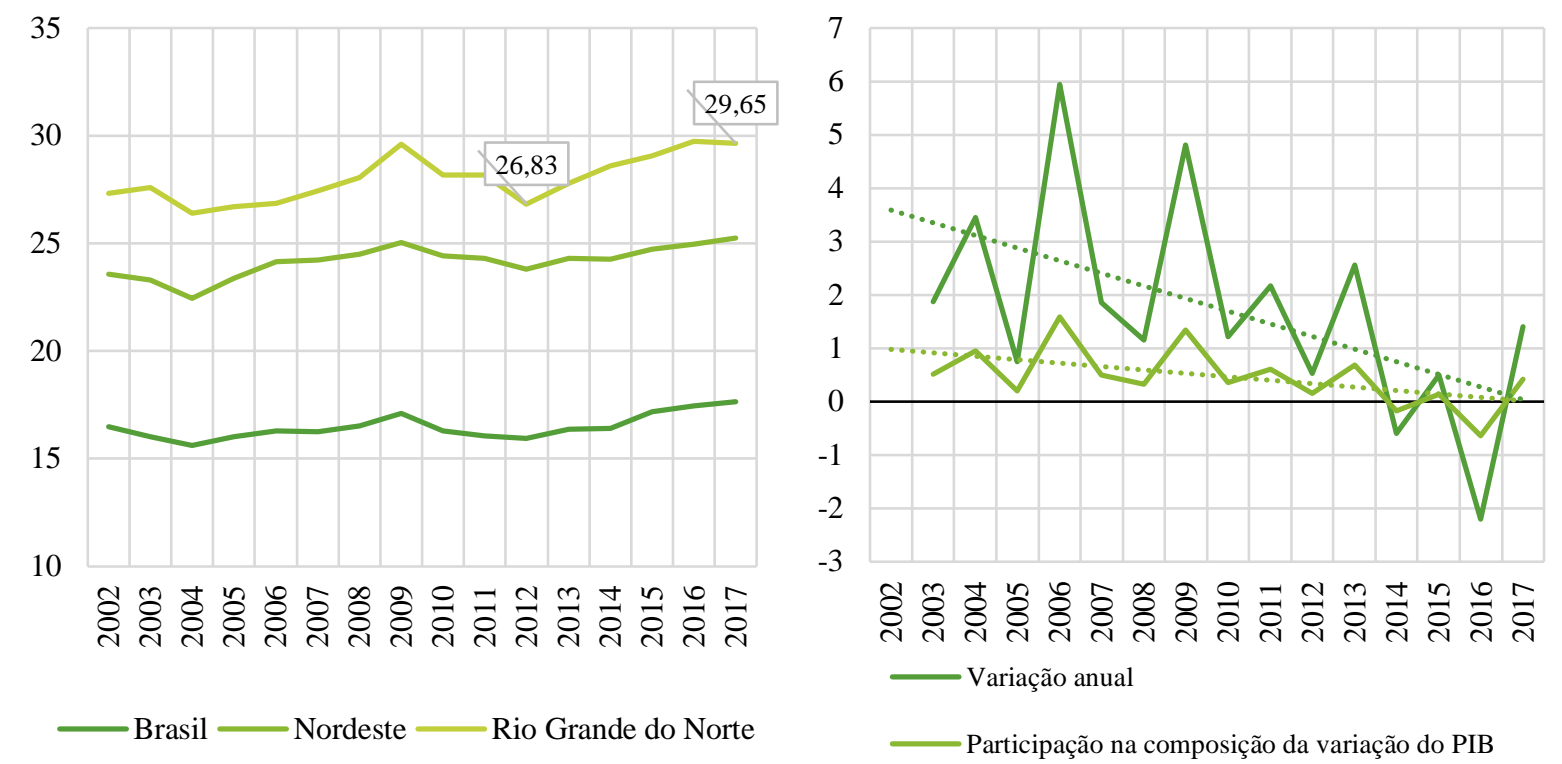

Fonte: Elaboração própria com base em dados do SCR/IBGE. Nota: a variável de composição do setor público no crescimento do PIB foi calculada pelo método tradicional, em que o peso é a participação do setor no valor agregado 5 .

A variação do valor agregado pelo setor público (VSP) apresentou uma tendência de queda ao longo de todo o período que vai de 2002 a 2017, em ciclos de expansão e declínio em função do calendário eleitoral ${ }^{6}$, o que demonstra importância da deliberação política direta em torno de aproximadamente um terço do produto interno da economia potiguar. Além disso, a análise de decomposição da taxa de crescimento do PIB revela que a dinamicidade do VSP não foi suficiente para sustentar uma taxa de crescimento significativa, também apresentando tendência de queda (SILVA, 2019).

A partir dessas ressalvas, não é possível concluir de outra forma que, por essa via, se instala um horizonte de estagnação. Como consequência teleológica da tendência de aumento da importância do VSP na composição do valor agregado, a

\footnotetext{
${ }^{5}$ Part. $=\left({ }^{V S P_{t-1} / P I B}\right) *\left(V S P_{t-1} / V S P_{t}-1\right) E m$ que $V S P_{t}$ é o valor agregado pelo setor público no ano corrente, e $V S P_{t-1}$ no ano anterior.

${ }^{6}$ Em maior grau nos pleitos nacionais e do estado e em menor grau nos pleitos municipais
} 
partir de 2012, acompanhado da queda de variação desse componente e diminuição da importância do mesmo na taxa de crescimento. Se antes o aumento da importância do Estado (2004 a 2009) significava o ajuste necessário na oferta de bens públicos, a partir da recessão passou a representar o esmorecimento do setor privado.

O fato da expansão do produto no período de expansão ter se dado predominantemente no setor de comércio e serviços proporcionou um elevado impacto no nível de emprego do estado, a despeito de a maior taxa de crescimento observado no período ter sido 5,37\% em 2011. Isso ocorreu pela elevada capacidade de expansão da demanda por trabalho não especializado no setor, o que dirigiu a inclusão de 150 mil dos 211 mil novos trabalhadores formais entre 2004 e 2014 (SILVA, 2019).

Gráfico 5 - Taxa de crescimento dos empregos formais no Rio Grande do Norte (\%)

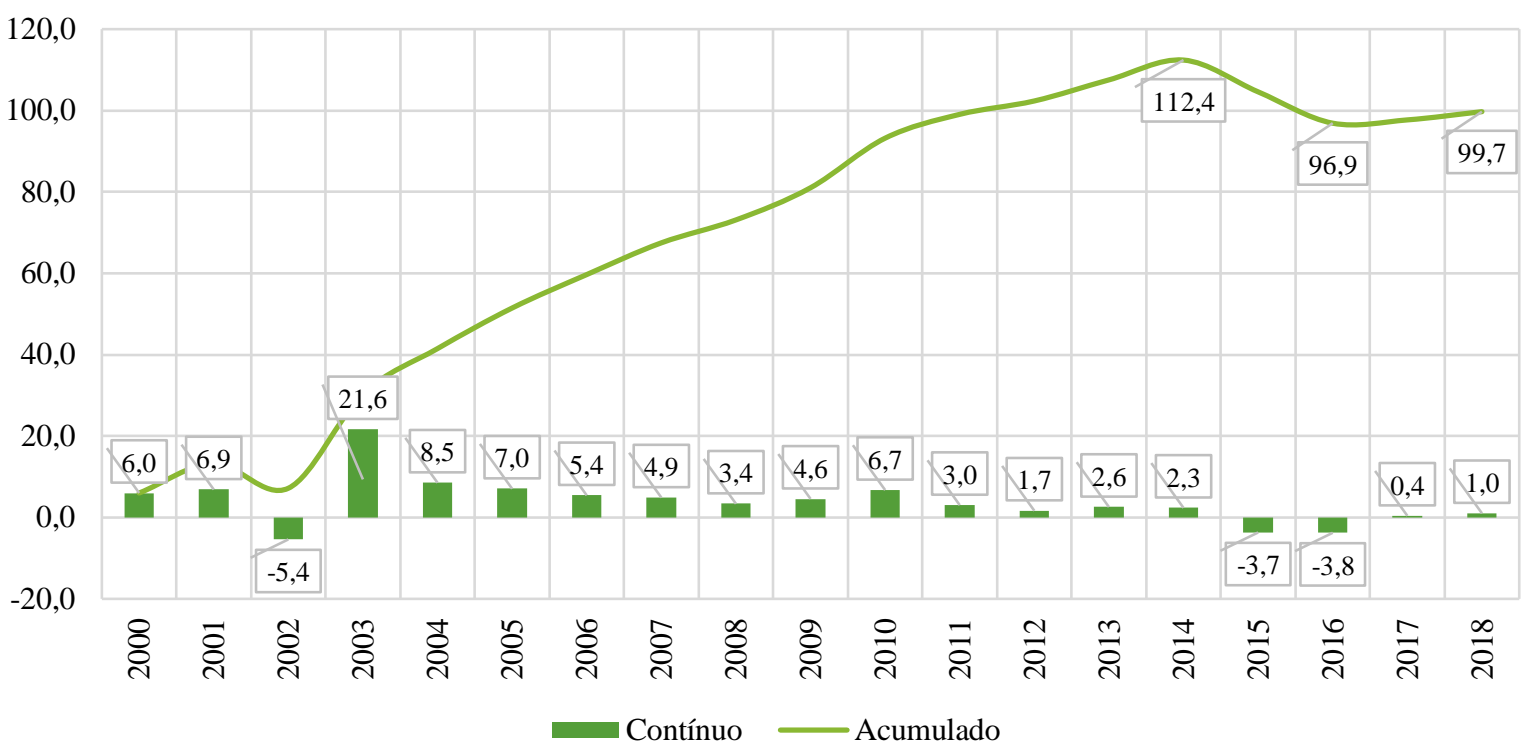

Fonte: Elaboração própria com base em dados da RAIS.

Contraditoriamente, o padrão de expansão econômica local, guiado pelo setor terciário, produziu as condições de sua instabilidade. Silva (2019) enuncia duas fontes de instabilidade para o padrão, a saber, seu caráter de sustentação exógena e sua estrutura pouco diversificada. Os vetores de demanda que adentraram a economia foram introduzidos nas cadeias de renda e gasto do estado, mas não se construíram endogenamente, a partir desses vetores, estruturas resilientes através da expansão da participação da indústria de transformação, sem assim proporcionar o aumento da complexidade do parque industrial local. 
No que concerne ao movimento de quebra estrutural da tendência de crescimento, é necessário enunciar os choques de demanda agregada e de política econômica, como os observados durante a desaceleração a partir de 2010 e a posterior crise em 2015, como capazes de interromper bruscamente a trajetória de crescimento iniciada. Através de redução do consumo, via redução de renda e crédito, são criados entraves que rapidamente contaminam o lado da oferta e reduzem a geração e proporcionam a destruição de empregos no curto prazo (SILVA, 2019). Porém a proporção crítica que a crise assumiu produziu um impacto que alterou drasticamente a perspectiva de crescimento, criou um ambiente de altas taxas de desemprego, subutilização da força de trabalho e informalidade (TROVÃO; ARAÚJO, 2020).

Depois de terem alcançado mínimas históricas no quarto trimestre de 2014 , as taxas de desocupação e subutilização da força de trabalho passaram a aumentar com a dissolução dos fluxos de demanda que permitiram sua expansão. Ambas as taxas saíram de, respectivamente, $10,4 \%$ e $25,2 \%$ para um pico de $16,3 \%$ e $34,6 \%$ no Rio Grande do Norte no primeiro semestre de 2017. Números que já se mostravam maiores do que os visualizados na conjuntura nacional em períodos de crescimento, agravaram-se amiúde, continuamente no caso da subutilização da força de trabalho e aumento da informalidade.

Gráficos 6 e 7- Taxa de desocupação e taxa de subutilização da força de trabalho com 14 anos ou mais (\%)
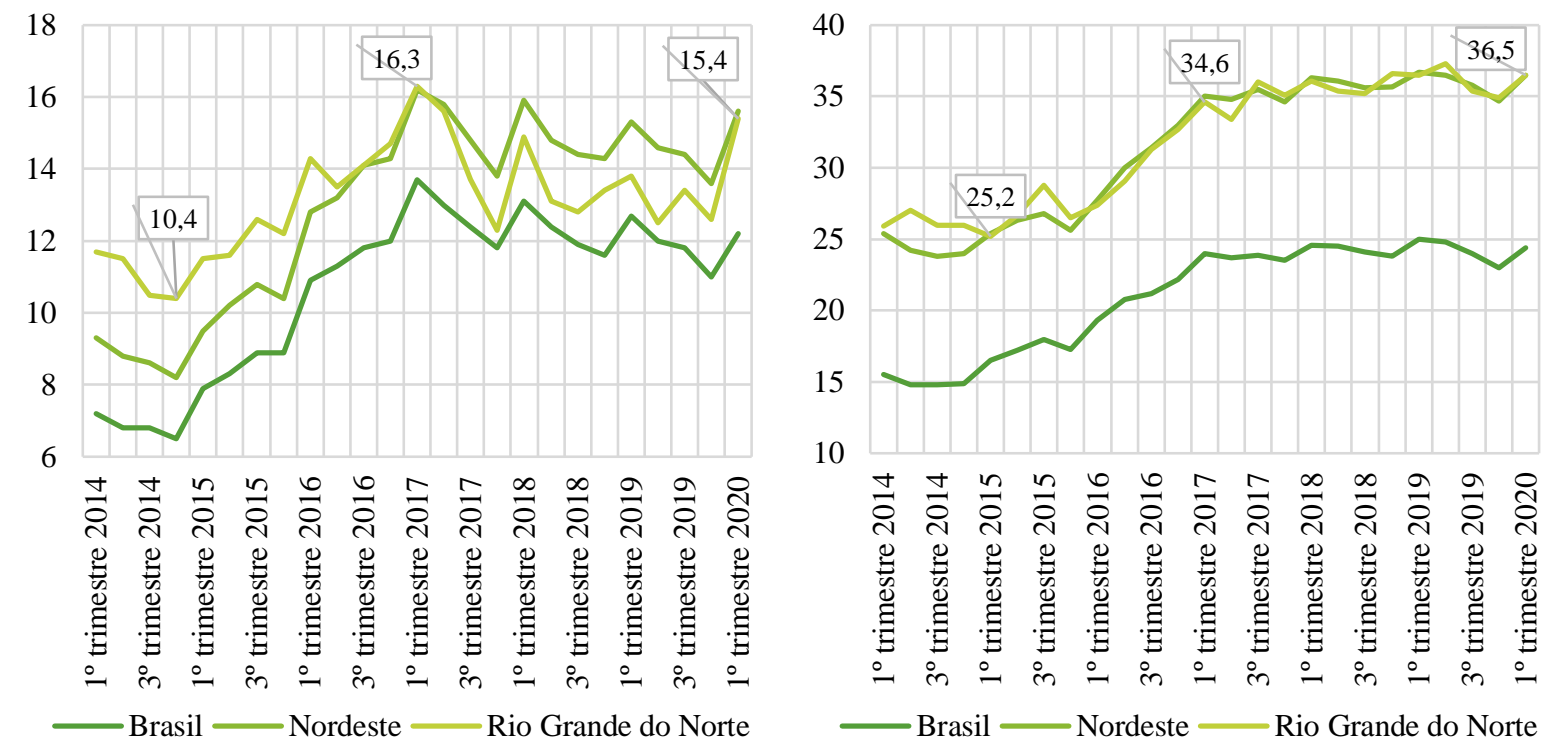

Fonte: Elaboração própria com base em dados da PNAD trimestral. 
No que concerne a taxa de desocupação, ocorreu um processo de lenta diminuição até o quarto trimestre de 2019, não explicado em sua totalidade pela geração extemporânea de postos de trabalho em ambiente de crise e estagnação, mas também pelo aumento do desalento de milhares de trabalhadores (SILVA, 2019).

Segundo o Comitê de Datação de Ciclos Econômicos (CODACE, 2020), ainda sem ter recuperado o nível de produto e emprego que a economia possuía ao final de 2014, a economia brasileira retornou para uma nova recessão no primeiro trimestre de 2020. Em agravo a essa afirmativa, logo ao fim do primeiro trimestre de 2020 uma pandemia de um vírus altamente contagioso toma proporções globais adentra o cenário econômico. No decorrer de cerca de 4 meses já se acumulam dezenas de milhares de mortes, acompanhada pela desativação em cadeia de atividades econômicas, haja visto o imperativo de isolamento social adotado para prevenir sua proliferação.

Os efeitos recessivos surgem como um choque de oferta devido as restrições impostas as atividades de serviços e comércio não essenciais e circulação de trabalhadores e consumidores, interrompendo fluxos de gasto deprimindo as receitas agregadas do setor terciário, aumentado os estoques e reduzindo as expectativas de consumo futuro.

Esse processo transmite à indústria e ao setor primário, em função da lógica de insumo-produto, os impactos recessivos, visto o defenestrar da esfera de circulação. Ambos, indústria e setor primário, também são prejudicados pelo afastamento da mão de obra das plantas de produção em virtude das restrições institucionais pró-isolamento (GUERRIERI et al, 2020; MELO et al, 2020).

Regionalmente a questão pode ser visualizada como uma inflexão mais aguda, posto que se somam às trajetórias de crise diferenciadas em escala novas fontes de recessão e desemprego. A exemplo desse fato, no espaço econômico do Rio Grande do Norte, não é possível afirmar que durante o ciclo de crescimento que perdurou até 2014 o estado não viveu uma crise de desemprego estrutural. Mesmo com o expressivo crescimento do emprego e renda, as taxas de desocupação registradas no auge da expansão foram superiores as observadas nos espaços centrais.

A condição de atraso da periferia do capitalismo implica que sempre que rebatimentos internos de ondas de crescimento adentram o espaço sem, no entanto, modificar qualitativamente as estruturas produtivas e sociais, persistem as dessemelhanças entre os espaços regionais. $\mathrm{Na}$ chegada da parte descendente do 
ciclo a periferia parte, portanto, de um nível de produto, emprego menores e baixa capacidade de intervenção dos mecanismos de Estado.

Evidentemente que a sobreposição entre esses efeitos inexoravelmente resultará em uma profunda recessão que consumirá em escala considerável ganhos sociais e econômicos construídos ao longo desse primeiro sexto de século. $E$ é, principalmente, no mercado de trabalho que essa desconstrução tem sua pior face.

O corte nos fluxos gasto supply-side implica, tudo mais constante, em demissões em massa e aceleração da taxa de desemprego a um patamar nunca visto em um curto intervalo de tempo. Por sua vez, a redução dos níveis de emprego em uma economia implica, demand-side, em uma nova perda de fluxos de gasto e receitas agregadas aprofundando a crise em um ciclo regressivo contínuo (LUCCHESE; PIANTA, 2020; MELO et al, 2020).

Esse aspecto é crítico em relação ao mercado de trabalho do Rio grande do Norte, devido a força de trabalho estar alocada principalmente no comércio e serviços, conforme supracitado, justamente os setores em que se dá o choque recessivo inicial. Parece ser uma hipótese forte que a extensão inicial da crise, bem como seus rebatimentos internos via efeitos multiplicadores, será maior que os visualizados em outros contextos regionais.

Gráficos 8 e 9 - Índice de volume de serviços e de vendas no comércio varejista dessazonalizado do Rio Grande do Norte $(01-2014-05-2020,2014=100)$
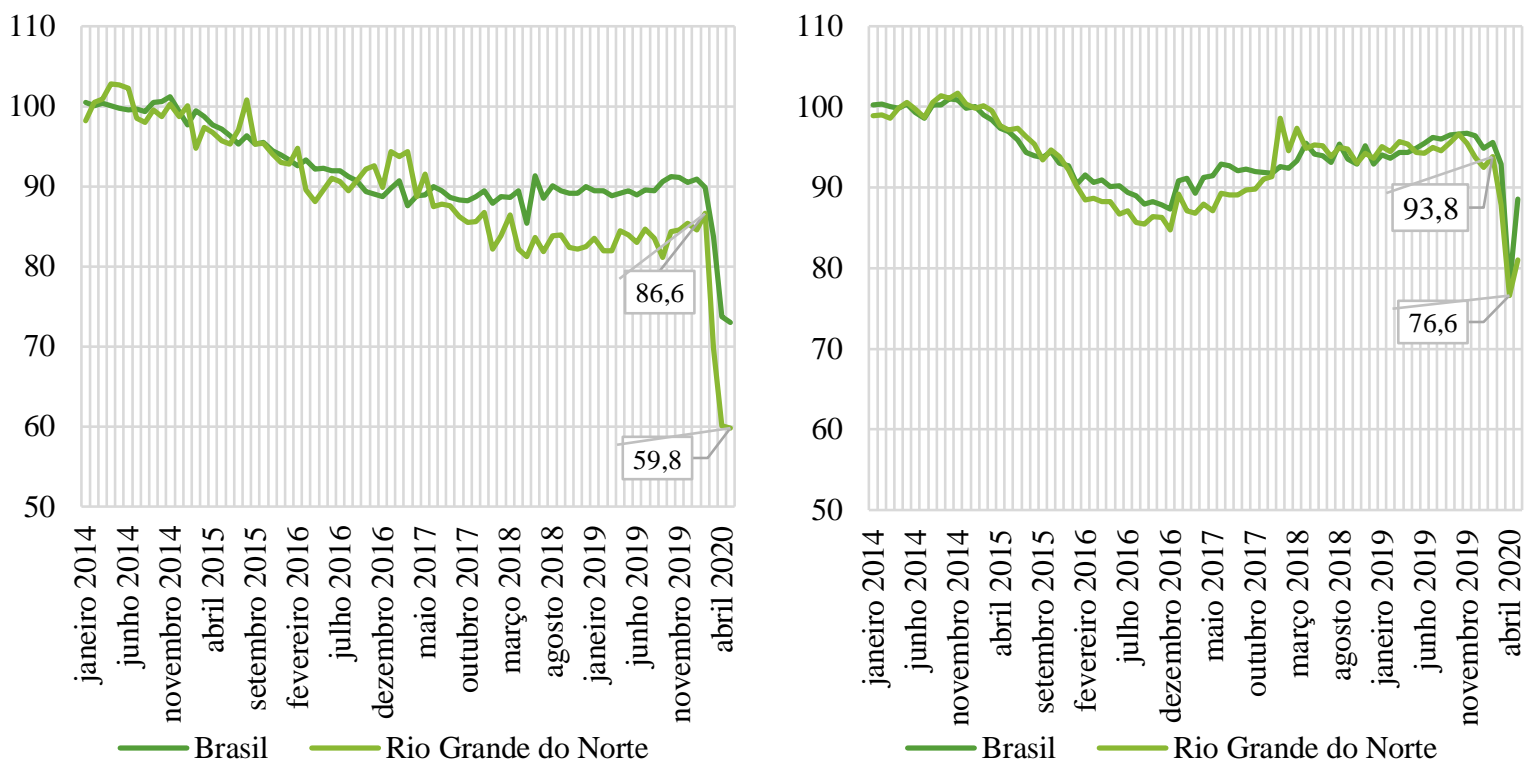

Fonte: Elaboração própria com base em dados da Pesquisa Mensal do Comércio e Pesquisa Mensal de Serviços, SIDRA/IBGE 
Frente a isso, os dados da Pesquisa Mensal de Comércio (PMC) e da Pesquisa Mensal de Serviços (PMS) corroboram à assertiva, mostrando que a queda no volume de serviços prestados e de vendas no estado caíram de forma mais célere que no Brasil. Enquanto a variação no volume de serviços no estado foi de $-30,9 \%$ entre fevereiro e maio de 2020 , no Brasil esse número foi de $-18,8 \%$, já o comércio varejista local perdeu $13,6 \%$ e no Brasil 7,3\% no mesmo período.

O papel do Estado Nacional na conjuntura de crise generalizada em âmbito global volta a superfície do debate econômico e na ação anticíclica dos EstadosNação internacionalmente através de massivos estímulos baseados em política fiscal. A montagem de um welfare-state emergencial frente a livre operação dos mercados surgiu como imperativo frente ao Market Lockdown e a ameaça de recessão aberta e destruição de empregos, levando, sobretudo, ao entendimento da saúde enquanto bem público (LUCCHESE; PIANTA, 2020). No Brasil, por ação do legislativo, foi criado um pacote de renda emergencial para os trabalhadores informais, desocupados e beneficiários do programa Bolsa-Família buscando suprir parte das perdas de renda em consequência do isolamento social.

Sobre o assunto Trovão e Araújo (2020) argumentam que a implantação do auxílio se mostrou tardia e insuficiente, a partir de três principais apontamentos. Em primeiro lugar, o atraso da ação do governo na distribuição dos recursos, permitindo um espaço amplo de prejuízos aos trabalhadores. Em segundo lugar, a burocracia envolvida no cadastro e a falta de uma logística que otimizasse o acesso aos recursos de forma segura, com garantia de liquidez aos trabalhadores, provocou ainda mais desajuste temporal na busca por compensar a perda de rendas.

Por último, e mais importante, os autores mostram que o montante de 600 reais dos benefícios é insuficiente para repor as perdas de renda dos trabalhadores informais.

[...] estimativas realizadas para o Rio Grande do Norte, estado da Federação que possui um rendimento médio $17 \%$ inferior à média nacional, permitem observar que um valor médio para o auxílio ligeiramente superior a $R \$ 600,00$ seria suficiente para compensar possíveis perdas em termos de massa de rendimentos do segmento dos informais. No entanto, esse efeito não se verificaria uniformemente em todo o estado. A RMN tenderá a sofrer mais que a média do $\mathrm{RN}$ por apresentar uma renda média maior para o informal e menor incidência do PBF e de desocupação. A RMN teria que ser contemplada por um auxílio médio de $R \$ 893,99$ para que esse segmento da 
população não incorresse em perdas agregadas para a massa de renda (TROVẪO; ARAÚJO, 2020, p. 220) ${ }^{7}$

Carlsson-Szlezak, Reeves e Swartz (2020) levantaram três possibilidades do formato em que se dará o comportamento da variação do produto agregado. A perspectiva mais otimista é de que o choque de oferta tenha efeito passageiro a curto prazo sobre a atividade econômica, resultando em uma recuperação em forma de V. O segundo cenário, menos otimista, prevê que certa persistência dos efeitos recessivos, resultando em uma curva em formato de $U$, o que, segundo os autores é mais plausível que ocorra no caso da crise causada pelo vírus, apesar de ainda ser necessário observar mais evidências para se extrair uma conclusão. O último cenário considera a habilidade da recessão provocar danos estruturais à economia, com falências suply-side, atingindo o mercado de trabalho, a formação de capital fixo e, portanto, a produtividade agregada, resultando em uma curva em formato de $\mathrm{L}$.

Figura 1 - Três cenários a partir do choque de oferta

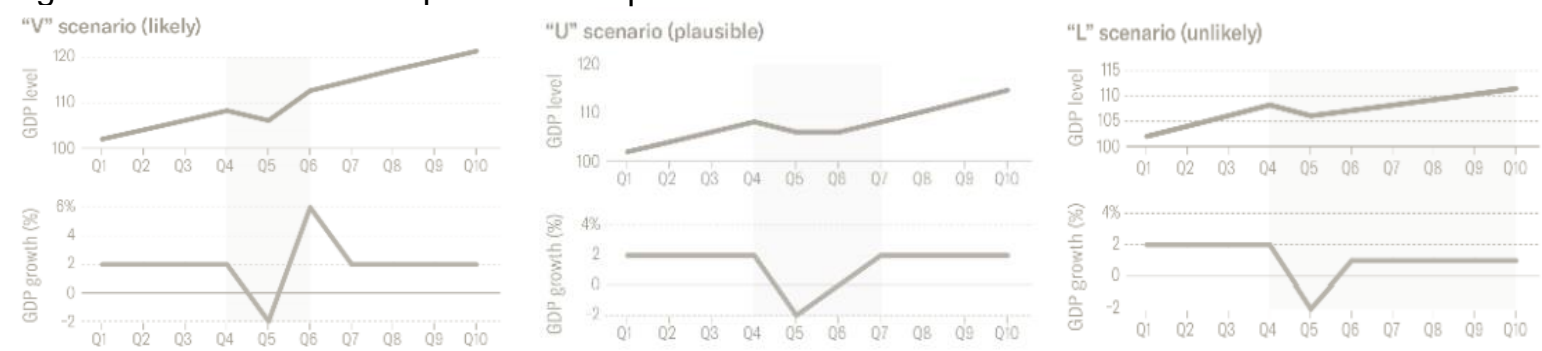

Fonte: CARLSSON-SZLEZAK; REEVES; SWARTZ (2020)

Para os autores, o pior cenário não é factível, mas deve-se contextualizar seu argumento como válido no espaço econômico dos países desenvolvidos. A perda de renda agregada é liderada pelo setor informal, e pela redução do nível de emprego das pequenas e médias empresas com reduzida capacidade financeira. No contexto do Rio Grande do Norte, os danos estruturais se tornam factíveis na medida em que a composição da matriz produtiva é dominada pelas estruturas mais atingidas pela nova crise.

Assim, a redução da massa agregada de salários, assume, portanto, a capacidade de tornar plausível a hipótese de o choque inicial de oferta assumir uma tendência persistente sobre o nível de produto. No caso brasileiro, a reorientação da

\footnotetext{
${ }^{7}$ RMN refere-se a Região Metropolitana de Natal, e PBF ao programa bolsa família.
} 
tendência, a partir desse efeito, soma-se a uma já iniciada recessão no primeiro trimestre de 2020, o que ceteris paribus aponta para um horizonte de recessão profunda.

\section{A EVOLUÇÃO RECENTE DO FEDERALISMO FISCAL NO BRASIL E AS QUESTÕES ESTRUTURAIS DO RIO GRANDE DO NORTE}

O Brasil, enquanto estado federal, se constitui como uma organização descentralizada político e administrativamente. Esta federação ergue-se a partir de uma repartição de competências entre o governo central e os locais, compartilhando deliberações e não se permitindo o direito de secessão. $O$ fim do regime militar ensejou um novo pacto federativo materializado na carta magna de 1988 (RAMMÊ, 2015).

No novo estatuto constitucional modificaram-se algumas características do modelo federativo brasileiro, tornando-o mais democrático, mas não necessariamente mais descentralizado. Tornou-se mais democrático porque incluiu os Municípios como ente federal, possibilitando igualdade institucional com os estados e a União. Esse fato tornou a federação brasileira única, pois nenhuma outra federação do mundo inclui os municípios como entes federativos (RAMMÊ, 2015).

Essa busca por mais democracia, típica de um período de pós-ditadura, criou muitas expectativas no que consiste a descentralização de poder, que foram gradualmente solapadas por crises fiscais, que tornaram as atitudes advindas da união, mais paternalistas e centralizadoras, principalmente no trato fiscal. Esse paternalismo, traço típico inerente a constituição da nação, se constitui uma outra face do centralismo fiscal que se verificou nos anos seguintes a promulgação da constituição (RAMMÊ, 2015).

O centralismo fiscal brasileiro assemelha-se ao "federalismo centrípeto" que se constituem como modelo no qual opta-se "pelo fortalecimento do poder central em detrimento do poder local. Ou seja, poderes, encargos e competências tendem a ficar mais concentrados na esfera federal (União) do que nas esferas regionais (Estados) e locais (Municípios) (RAMMÊ, 2015, p. 2308).

Afirmamos que somente se assemelha, mas não se identifica, pois enquanto no federalismo centrípeto a opção pelo fortalecimento do poder central partiu do constituinte derivado, no Brasil essa opção ocorre pelo estimulo do ente União, em 
promover uma concentração fiscal em detrimento dos demais entes federativos, divergindo do constituinte originário que preconizava um federação mais democrática com a inclusão dos municípios. No Brasil se constitui um movimento "centrípeto bastardo" e combatido pelos demais entes federativos que vem crescer as responsabilidades sem o correspondente crescimento dos recursos necessários as mencionadas responsabilidades.

Com o marco constitucional de 1988, se buscou uma nova configuração do federalismo brasileiro em negação ao pacto autoritário e centralizador político e fiscal da ditadura militar (AFFONSO, 1994). No entanto, como argumenta Lopreato (2018), o debacle da situação econômica do país, com a crise que se arrastou desde o início da década de 1980, impôs aos estados e a União um rigoroso ajuste fiscal, a que seguiu a implantação do plano real, e proporcionou a revisão do padrão de intervenção do Estado na economia. É essa revisão que se podemos denominar de novo federalismo centrípeto bastardo pois prejudica Municípios e Estados em benefício da União.

O setor público ficou marcado pelas privatizações de empresas e bancos estaduais, vendas de ativos, pelos acordos de renegociação das dívidas e a criação de mecanismos de controle de endividamento, sacramentados na Lei de Responsabilidade Fiscal de 2001. Para Lopreato (2000), esse movimento levou a alterações profundas da questão do federalismo fiscal, pois retirou dos estados certa autonomia de política fiscal, a saber, a capacidade de financiamento endógena de sua dívida e potenciais déficits.

Acompanhando da dinâmica medíocre da economia, até 2003, gerando, portanto, baixo crescimento de receitas próprias, os estados ficaram atados a lógica de ajuste fiscal, com obrigação de geração de superávits primários. Assim, apesar das propensas autonomias constitucionais dos estados, esses passaram a perder continuamente as condições fiscais de exercer o poder de intervenção econômica direta (TINOCO, 2018).

Apesar da manutenção do teor central dos marcos regulatórios da fiscalidade dos entes subnacionais, a melhora no crescimento da economia, a partir de 2004, ajudou a aliviar a pressão sob as finanças estaduais, reduzindo seu grau de endividamento. Houve um aumento na arrecadação de ICMS, principal imposto da 
composição de receitas próprias dos estados, além um desempenho favorável das transferências constitucionais (LOPREATO, 2018).

Nada obstante, o bom desempenho das finanças públicas nesse período logo encontrou seus limites estruturais. Com a desaceleração da economia, a partir de 2010, o resultado primário dos estados passou a incorrer em déficits, bem como os gastos, e sua composição, passaram a piorar. Em 2013, têm-se novamente um novo marco de deterioração das finanças estaduais, que seguiram em derrocada até a grave recessão de 2015 e 2016 . Essa nova quebra estrutural nas contas públicas dos entes federados ocorre em um contexto de elevadas e crescentes demandas sociais por serviços públicos essenciais, como saúde, segurança pública e educação básica (TINOCO, 2018).

Gráfico 8 - Dívida Consolidada Líquida sobre Receita Corrente Líquida dos Estados (\%)

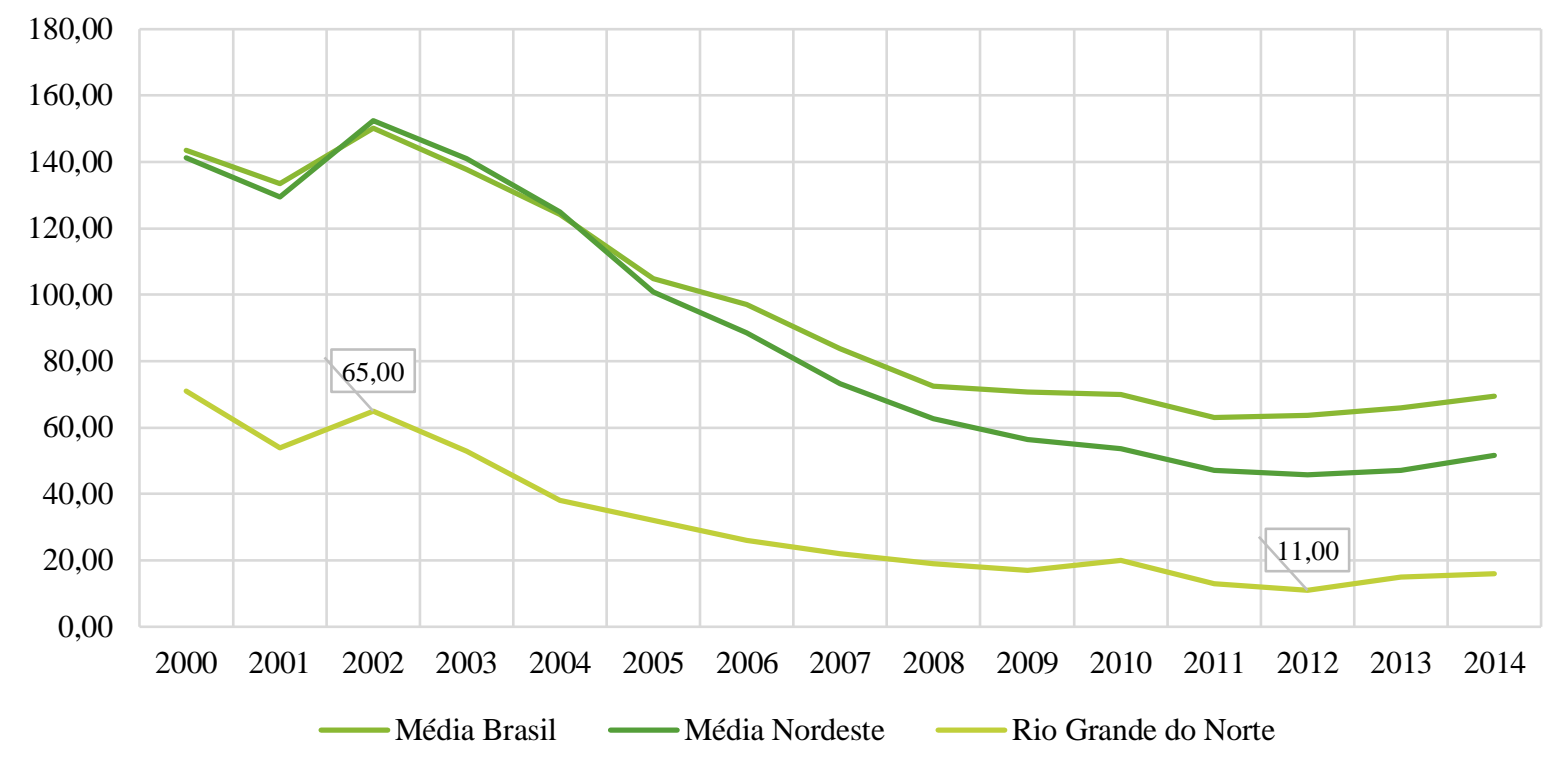

Fonte: Elaboração própria com base em dados do STN/SICONFI.

No Rio Grande do Norte, o movimento em nada se distingue do quadro geral apresentado, exceto em termos da escala de endividamento, dado que a capacidade fiscal e financeira do estado é proporcional ao nível relativo de produto frente as outras unidades federadas. Enquanto o indicador de endividamento médio dos estados do Brasil variou de 150,19\%, no platô em 2002, a 63,04\% em 2012, nos estados do Nordeste esse indicador foi de, respectivamente, 152,44\% e 45,78\%, já no Rio Grande do Norte, o ápice da dívida foi de $65 \%$ e o ponto de baixa de $11 \%$.

O tratamento institucional igualitário dos entes federados nos Programas de Reestruturação Fiscal e Financeira e na Lei de Responsabilidade Fiscal, enquanto 
esses são flagrantemente diferentes, para Mora e Giambiagi (2007) não constituiu um problema, pois "o resultado fiscal das unidades da federação foi excelente, revertendo o déficit e contribuindo de modo expressivo para o esforço empreendido pelo setor público consolidado" (MORA; GIAMBIAGI, 2007, p. 22). No entanto, a boa situação das contas públicas e redução dos passivos financeiros escondeu, no caso do Rio Grande do Norte, questões estruturais de longo prazo.

Não foi por simples probidade administrativa que o endividamento do Estado se destacou abaixo da média regional e nacional, mas pela baixa capacidade de financiamento do setor público local. Ainda que haja espaço de endividamento, seja institucional ou por boas condições de rolagem da dívida, o Estado tem dificuldades em captar recursos devido as incertezas elevadas em função da escala reduzida de atividade econômica e, portanto, de arrecadação, além da elevada importância que as transferências constitucionais, de determinação exógena, têm na composição de receitas.

Besley e Persson (2010), mostram que a relação simbiótica entre Estados fortes e mercados consolidados implica que uma evolução em trajetórias distintas dessas estruturas não é possível. Em um contexto regional, com ausência de autonomia de política fiscal, o baixo dinamismo e complexidade da economia implica também em um Estado com baixa capacidade endógena de intervenção, de criar e sustentar políticas e regular os mercados, além de prover bens públicos essenciais.

Nos termos de Myrdal (1968), a pobreza torna-se sua própria causa em um ciclo regressivo, no qual o Estado sem condições de prover os bens públicos básicos, infraestrutura adequada e políticas sociais e produtivas, necessárias para elevar o nível de produto per capita acima do crescimento demográfico, diminui a capacidade de crescimento a longo prazo no território. As condições pelas quais o desenvolvimento econômico e social poderia ocorrer ficam comprometidas e decaem em uma armadilha de estagnação e baixo nível de renda, descrita por Nelson (1956), cujas condicionantes específicos locais foram em parte demonstrados por Silva (2019). 


\section{O PROBLEMA DA DETERIORAÇÃO FISCAL NO RN}

A complicada relação entre Estado e mercados sob o contexto do subdesenvolvimento retorna a superfície em conjuntura de crise. Com a reversão do quadro macroeconômico favorável e o início da contração do nível de produto, em 2015 e 2016, os efeitos regionais se apresentaram diferenciados em escala e em perspectivas de recuperação. Para a esfera pública essa afirmativa também é válida na medida em que varia o poder da organização local de Estado no espaço econômico, poder de intervir nos mercados guiando o processo de desenvolvimento (BESLEY; PERSSON, 2010).

Tabela 1 - Componentes da despesa e despesa primária real total do Estado do Rio Grande do Norte

\begin{tabular}{c|ccc}
\hline & $\begin{array}{c}\text { Pessoal e Encargos } \\
\text { Sociais (\%) }\end{array}$ & $\begin{array}{c}\text { Investimento } \\
\text { Contábil (\%) }\end{array}$ & $\begin{array}{c}\text { Despesa Primária } \\
\text { Real Total (R\$) }\end{array}$ \\
\hline $\mathbf{2 0 1 5}$ & 66,74 & 5,57 & 12.573 .147 .350 \\
\hline $\mathbf{2 0 1 6}$ & 77,46 & 5,74 & 10.700 .116 .584 \\
\hline $\mathbf{2 0 1 7}$ & 76,68 & 4,98 & 11.674 .265 .390 \\
\hline $\mathbf{2 0 1 8}$ & 71,73 & 9,37 & 10.555 .798 .572 \\
\hline $\mathbf{2 0 1 9}$ & 74,39 & 5,99 & 11.395 .187 .511 \\
\hline
\end{tabular}

Fonte: Elaboração própria com base em dados do STN/SICONFI. Nota: Despesa primária a preços de 2019, deflacionado a partir do IPCA.

Tabela 2 - Componentes da receita e receita primária real total do Estado do Rio Grande do Norte

\begin{tabular}{c|ccc}
\hline & ICMS (\%) & Transferências (\%) & $\begin{array}{c}\text { Receita Primária } \\
\text { Real Total (R\$) }\end{array}$ \\
\hline $\mathbf{2 0 1 5}$ & 36,21 & 37,90 & 12.182 .327 .700 \\
\hline $\mathbf{2 0 1 6}$ & 31,30 & 44,37 & 10.734 .639 .215 \\
\hline $\mathbf{2 0 1 7}$ & 30,71 & 44,26 & 11.217 .481 .374 \\
\hline $\mathbf{2 0 1 8}$ & 31,91 & 52,06 & 10.722 .393 .816 \\
\hline $\mathbf{2 0 1 9}$ & 32,59 & 45,31 & 10.780 .610 .884 \\
\hline
\end{tabular}

Fonte: Elaboração própria com base em dados do STN/SICONFI. Nota: Receita primária a preços de 2019, deflacionado a partir do IPCA.

No caso do Rio Grande do Norte os elementos da crise recente reverberam nas finanças públicas e, portanto, alterando sua capacidade de intervenção. De imediato, o Estado não ampliou suas receitas tão rápido quanto suas despesas. Enquanto as receitas primárias declinavam em termos reais (ver tabela 02), as despesas com pessoal e encargos sociais cresciam em participação e absolutamente (ver tabela 01) implicando em um volume de despesa primária crescente que se tornou superior a receita em três dos cinco anos analisados. Note-se que o saldo positivo nos dois anos em que a receita é superior a despesa não sana o déficit dos anos negativos, implicando em aumento do endividamento do estado. O resultado primário negativo é 
crescente comprovando a fragilidade das finanças estaduais para fazer frente as suas despesas como também a possibilidade de endividamento e rolagem dessa dívida.

Quanto a composição das despesas, observa-se que o espaço fiscal para investimentos tem diminuído significativamente, o que demonstra a inabilidade endógena de construir estruturas resilientes sob as quais podem se assentar um processo contínuo de desenvolvimento. Do percentual de despesas com investimento que flutua em torno de 5,5\% em anos não eleitorais, o que de fato se constitui como investimento no sentido econômico é uma fração ínfima, sendo a maior parte investimento na manutenção da própria máquina pública. Com a crescente participação do funcionalismo nas despesas primárias, devido, principalmente, a baixa dinâmica do crescimento das receitas, o governo estadual se engessa cada vez mais operando de forma a tentar garantir seu próprio funcionamento.

Tabela 3 - Resultado primário e variação real de despesas e receitas do Estado do Rio Grande do Norte

\begin{tabular}{c|rccc}
\hline & $\begin{array}{c}\text { Resultado } \\
\text { Primário (R\$) }\end{array}$ & $\begin{array}{c}\text { Despesa Primária } \\
\text { Total - I (\%) }\end{array}$ & $\begin{array}{c}\text { Receita Primária } \\
\text { Total - II (\%) }\end{array}$ & $\begin{array}{c}\text { Diferença } \\
\text { II - I (pp.) }\end{array}$ \\
\hline $\mathbf{2 0 1 5}$ & $-390.819 .649,6$ & & & $-11,88$ \\
\hline $\mathbf{2 0 1 6}$ & $34.522 .630,8$ & $-14,90$ & 4,50 & 3,01 \\
\hline $\mathbf{2 0 1 7}$ & $-456.784 .015,2$ & 9,10 & $-4,41$ & $-4,61$ \\
\hline $\mathbf{2 0 1 8}$ & $166.595 .244,2$ & $-9,58$ & 0,54 & 5,17 \\
\hline $\mathbf{2 0 1 9}$ & $-614.576 .626,8$ & 7,95 & $-7,41$ \\
\hline
\end{tabular}

Fonte: Elaboração própria com base em dados do STN/SICONFI. Nota: A preços de 2019, deflacionado a partir do IPCA.

A tabela 3 nos mostra os diferentes percentuais de crescimento das despesas e receitas, conformando uma necessária alteração na estrutura fiscal do visando evitar um crescimento explosivo do endividamento público estadual. Apesar da deterioração das contas estaduais ser normalmente atribuída ao gasto com pessoal, principalmente com os inativos e aposentados, ela é função do declínio do nível de emprego da economia. $\mathrm{O}$ crescimento do desemprego provocado pelas medidas de austeridade implantadas desde 2015, que reduzem o investimento público e privado, gerando desemprego e redução da massa salarial, afeta o consumo e, consequentemente, o recolhimento do Imposto sob Circulação de Mercadorias e Serviços (ICMS), principal fonte endógena de recursos tributários do estado.

Consubstancia essa afirmação, o fato das receitas advindas de ICMS estarem em queda na participação das receitas totais enquanto as transferências ganham 
maior peso. A queda real na arrecadação de cerca de 1,2 bilhões entre 2015 e 2019 deve-se em maior parte se devem às perdas de arrecadação endógenas, que acumularam queda real de $20,3 \%$, a medida em que as transferências variaram positivamente em $5,8 \%$.

O que se pode inferir dos dados e informações até aqui expostos, é que o estado encontra-se em uma situação financeira delicada, pois o crescimento das despesas supera as receitas, gerando déficits contínuos e crescentes, implicando na necessária contensão das despesas e buscas por novas fontes de recursos, com o desiderato de evitar um crescimento explosivo da dívida estadual com os consequentes corolários do endividamento profundo.

Acrescente-se a problemática do endividamento fruto da crise econômica e conjunto com as medidas de austeridade por parte do governo federal a nova crise provocada pela pandemia do coronavírus. Essa nova crise aprofunda a anterior por atuar em diversas dimensões. Pelo lado da oferta ao obstaculizar o funcionamento das empresas, provocando a parada súbita com a ampliação do desemprego e a redução da renda da população. Pelo lado da demanda. Pelo lado da tributação, reduz a capacidade de arrecadação do estado contribuído para uma forte redução dos recursos próprios do estado. Amplia os gastos necessários e inesperados com saúde a patamares inesperados.

A ampliação inesperada da demanda por bens de saúde, respiradores, medicamentos, máscaras, etc., elevou os preços provocando escassez e dificuldade para o estado adquirir tais bens e serviços extremamente necessários no período da pandemia. Dado tais contextos de deterioração da arrecadação em conjunto com aumento significativo dos gastos, urge para o estado rever sua estrutura tributária, que também é restringida pelos limites constitucionais ao poder de tributar estabelecido pela carta de 1988. Além disso, a alternativa é recorrer ao governo federal, que já vem a muito tempo restringindo as possibilidades de transferência de recursos para estados e municípios materializando o movimento centrípeto bastardo já mencionado.

\section{A CRISE ECONÔMICA E A PANDEMIA DO CORONAVÍRUS: PERSPECTIVAS PARA O PÓS-PANDEMIA}

No contexto de crise econômica, COVID-19, a inexistência de crescimento na demanda efetiva e baixas expectativas de vendas e lucros, os recursos excedentes 
dos mais ricos tendem a ir para o mercado financeiro, não contribuindo para a produção de bens e serviços, muito menos para a geração de emprego e renda. $A$ ausência de expectativas positivas do rápido crescimento da economia em conjunto com uma capacidade produtiva ociosa elevada e generalizada em quase todos os setores tornam-se um óbice ao investimento privado que permitiriam um efetivo retorno ao crescimento econômico. Nesse diapasão, as taxas de crescimento da produção de bens e serviços iniciaram pela utilização da capacidade produtiva vigente. Essa ação tende a afetar pouco o mercado de trabalho em contexto de uso intensivo do capital e das tecnologias em detrimento do uso da força de trabalho.

Dado a pandemia, alguns setores mantiveram-se ativos e até mesmo com taxas de crescimento, a exemplo o varejo de alimentos, os setores produtores de equipamentos proteção individual no âmbito da saúde, os serviços em saúde, etc. Porém, esses poucos setores não conseguem evitar a recessão econômica prevista para o Brasil no ano de 2020, que pode atingir os $6 \%$ segundo o Bacen (BCB, 2020). Embora o Bacen apresente para 2021/2022 uma expectativa por demais positivas de crescimento de $3,0 \%$ e $5,0 \%$ respectivamente. As reformas institucionais e quadro econômico atual dificilmente possibilitam tais taxas de crescimento. No entanto, mesmo que tais taxas sejam alcançadas não revertem as perdas ocorridas antes, nem resolvem os problemas estruturais de endividamento do estado.

Alguns analistas de mercados concordam com concepção de que o Bacen apresenta positivismo elevado, enquanto outros, em uma avaliação quantitativa preconizam que um crescimento de 3,0\%, em um base comprimida por 3 anos de queda $(2015,2015$ e 2020) que chegam a um declínio de mais de 14\% (se as expectativas para 2020 se confirmarem em aproximadamente $7 \%$ ) não será difícil de ser alcançada (BATISTA, 2002). Os economistas que duvidam de tal crescimento consideram que as estruturas produtivas ociosas poderiam até permitir esse crescimento, mas dado que a demanda não crescerá significativamente por estar obstaculizada devido dispensa no transcurso da pandemia de muitos trabalhadores. Consequentemente, o não crescimento significativo da demanda por trabalhadores impede o crescimento das vendas, gerando uma expectativa acanhada de crescimento das mesmas e consequentemente um não retorno do investimento privado na magnitude necessária para garantir esse crescimento econômico. Nesse 
diapasão, esses economistas acreditam em um retorno gradual e lento do crescimento econômico.

Acrescentando novas questões a essa possível realidade de crescimento baixo, as reformas implantadas e previstas de efetivação da parte do governo, não colaboram para o retorno do emprego formal, fator fundamental para a efetivação do crescimento econômico no pós-pandemia. A flexibilização, a precarização e a redução salarial da classe trabalhadora fragilizam o mercado de trabalho e ratifica uma perda de poder aquisitivo por parte dessa classe que é fundamental para efetivar o crescimento econômico. Aliado a corrosão do mercado de trabalho, a insuficiência do investimento público reflexo da emenda do teto de gastos não repercute positivamente no aumento das rendas do trabalho e, consequentemente, nas vendas varejo obstando assim as expectativas do setor privado que não amplia o investimento produtivo. Nesse diapasão, temos todas as condições para um ínfimo crescimento econômico, coeteris paribus, nos próximos anos.

\section{CONSIDERAÇÕES FINAIS}

O contexto social, econômico e político não apresenta os melhores panoramas para a população do Rio Grande do Norte. Conforme demonstrou-se a baixa capacidade e campo de atuação do Estado, em meio a inexistência de reformas estruturais, se confrontam contraditoriamente, impedindo uma atuação antirecessiva e desenvolvimentista. O somatório dos fracassos históricos na tentativa de superar os problemas seculares do subdesenvolvimento, devido as políticas equivocadas, resultou na incapacidade circunstância de investimento do Estado. Incapacidade de garantir endogenamente suas obrigações constitucionais e muito longe de alguma capacidade de efetivação do seu papel de incentivador e de planejamento para o desenvolvimento econômico.

Esse contexto supramencionado, na dimensão conjuntural, não será imediatamente pior devido ao auxílio emergencial, arrancado a "fórceps" do Governo Federal. Também não será significativamente melhor porque sua implantação do auxílio se mostrou tardia e insuficiente, com valores ínfimos e burocracia que se tornou um óbice para muitos pobres. Conforme mostrado anteriormente, a burocracia enredada no cadastro e ausência de uma logística que facilitasse o acesso aos 
recursos de forma segura, provocaram ainda mais desajuste temporal na busca por compensação frente a perda de rendas.

A perspectiva mais plausível, embora não tão otimista, quanto ao contexto de crise econômica e pandêmica, é de que o choque de oferta tenha efeito de médio prazo sobre a atividade econômica, demonstrando uma certa persistência dos efeitos recessivos, implicando em danos significativos sobre economia e sobre as condições de vida da classe trabalhadora e média. A perda de renda agregada, no período recessivo, será liderada pelo setor informal. A redução do nível de emprego das pequenas e médias empresas com reduzida capacidade financeira tenderá no médio prazo a se reverter se as medidas de política econômica forem implantadas de forma adequada. Caso contrário, a redução da massa agregada de salários assumirá a capacidade de tornar plausível a hipótese de o choque inicial de oferta assumir uma tendência persistente sobre o nível de produto.

Em síntese, o estado encontra-se em uma situação financeira delicada, pois o crescimento das despesas supera as receitas, gerando déficits contínuos e crescentes, implicando na necessária contensão das despesas e buscas por novas fontes de recursos, com a finalidade de evitar um crescimento explosivo da dívida estadual com os consequentes corolários do endividamento profundo. Essa nova crise política e de saúde aprofundou a crise econômica anterior por atuar em diversas dimensões. Obstaculizou o funcionamento das empresas, provocou a parada súbita com a ampliação do desemprego, reduziu a renda da população, reduziu a capacidade de arrecadação do estado, contribuiu com uma forte redução dos recursos próprios do estado e ampliou os gastos necessários para o combate a pandemia.

O contexto de deterioração econômico e fiscal impele o estado as necessárias reformas. Recorrer ao governo federal, que já vem a muito tempo restringindo as possibilidades de transferência de recursos para estados e municípios materializando o movimento centrípeto bastardo já mencionado, tornou-se também um imperativo. 


\section{REFERÊNCIAS}

AFFONSO, Rui de Britto Alvares. A crise da federação no Brasil. Ensaios FEE, v. 15, n. 2, p. 321-337, 1994.

ARAÚJO, D. S. Dinâmica econômica, urbanização e metropolização no Rio Grande do Norte (1940-2006). 2009. 345 f. Tese (Doutorado) - Curso de Economia, UNICAMP, Campinas, 2009.

BATISTA, Vera, Previsão de crescimento do PIB em 2021 divide economistas. Correio Brasiliense. Disponível em:

https://www.correiobraziliense.com.br/app/noticia/economia/2020/06/09/internas_eco nomia,862247/previsao-de-crescimento-do-pib-em-2021-divide-economistas.shtml. Acesso em: 20 jul. 2020.

BCB - BANCO CENTRAL DO BRASIL. Boletim Focus. Disponível em: https://www.bcb.gov.br/publicacoes/focus. Acesso em: 03 ago. 2020.

BESLEY, Timothy; PERSSON, Torsten. State Capacity, Conflict, and Development. Econometrica, [S.L.], v. 78, n. 1, p. 1-34, 2010. The Econometric Society. http://dx.doi.org/10.3982/ecta8073.

BRESSER-PEREIRA, Luiz Carlos. Estado, Estado-Nação e Formas de Intermediação

Política. Lua Nova, n. 100, p. 155-187, 2017.

CANO, Wilson. Desequilíbrios regionais e concentração industrial no Brasil: 1930-1970. 1981. 3 v. Tese (livre-docência) - Universidade Estadual de Campinas, Instituto de Economia, Instituto de Filosofia e Ciências Humanas, Campinas, SP. Disponível em: <http://www.repositorio.unicamp.br/handle/REPOSIP/285676>. Acesso em: 17 jul. 2018.

CARLSSON-SZLEZAK, Philipp; REEVES, Martin; SWARTZ, Paul. What coronavirus could mean for the global economy. Harvard Business Review, v. 3, 2020.

Disponível em: https://hbr.org/2020/03/what-coronavirus-could-mean-for-the-globaleconomy. Acesso em: 01 ago. 2020.

CODACE - COMITÊ DE DATAÇÃO DE CICLOS ECONÔMICOS. Comunicado de Datação de Ciclos Mensais Brasileiros Jun/2020. [S. L.]: CODACE, 2020. 4 p. Disponível em: https://portalibre.fgv.br/sites/default/files/2020-06/comunicado-docomite-de-datacao-de-ciclos-economicos-29_06_2020-1.pdf. Acesso em: 01 jul. 2020.

FAORO. Raymundo. Os Donos do Poder: Formação do patronato político brasileiro. 3ª edição. São Paulo: Globo, 2001.

FURTADO, Celso. Formação Econômica do Brasil. 32ª ed. São Paulo: Companhia Editora Nacional, 2003. 
GUERRIERI, Veronica; LORENZONI, Guido; STRAUB, Ludwig; WERNING, Iván. Macroeconomic Implications of COVID-19: can negative supply shocks cause demand shortages? Nber Working Paper, [s.I.], n. 26918, abr. 2020. National Bureau of Economic Research. http://dx.doi.org/10.3386/w26918.

LEFEBVRE, Henri. Espaço e Política: o direito à cidade II. Belo Horizonte: UFMG, 2016. $192 \mathrm{p}$.

LINDOSO, José Antônio Spinelli. Da Oligarquia Maranhão à Política do Seridó: 0 RN na Velha República. Natal: CCHLA -UFRN, 1992. 46 p.

LUCCHESE, Matteo; PIANTA, Mario. The Coming Coronavirus Crisis: what can we learn? Intereconomics, [S.L.], v. 55, n. 2, p. 98-104, mar. 2020. Springer Science and Business Media LLC. http://dx.doi.org/10.1007/s10272-020-0878-0.

LOPREATO, Francisco Luiz C. Governos Estaduais: O retorno a debilidade financeira. Campinas: Instituto de Economia - UNICAMP, texto para discussão, vol. 338, mai. 2018.

O endividamento dos governos estaduais nos anos 90. Economia e Sociedade, Campinas, v. 9, n. 2, p.117-158, dez. 2000.

MELLO, Guilherme.; OLIVEIRA, Ana Luíza Matos; GUIDOLIN, Ana Paula; CASO, Camila; DAVID, Grazielle; NASCIMENTO, Júlio Cezar; GONÇALVES, Ricardo; SEIXAS, Tiago. A Coronacrise: natureza, impactos e medidas de enfrentamento no Brasil e no mundo. Campinas: CECON, 2020. 23 p. Nota do Centro de Estudos de Conjuntura e Política Econômica - IE/UNICAMP. Disponível em:

https://www.eco.unicamp.br/images/arquivos/nota_cecon_coronacrise_natureza_imp actos_e_medidas_de_enfrentamento.pdf. Acesso em: 01 abr. 2020.

MORA, Mônica; GIAMBIAGI, Fabio. Federalismo e endividamento subnacional: uma discussão sobre a sustentabilidade da dívida estadual. Revista de Economia Política, [S.L.], v. 27, n. 3, p. 472-494, set. 2007. FapUNIFESP (SCIELO). http://dx.doi.org/10.1590/s0101-31572007000300009.

MENDES, Bruno Marinho Guimarães. Federalismo: um breve ensaio sobre o modelo brasileiro. 2015. 167 f. Dissertação (Mestrado) - Curso de Mestrado em Direito, Universidade de Lisboa, Lisboa, 2015.

MONTEIRO, Denise M. Introdução à história do Rio Grande do Norte. 3. Ed., Natal: EDUFRN, 2007, 217 p.

MYRDAL, Gunnar. Teoria econômica e regiões subdesenvolvidas. $2^{a}$ ed. Rio de Janeiro: Editora Saga, 1968. 210 p.

NELSON, Richard R. A Theory of the Low-Level Equilibrium Trap in Underdeveloped Economies. The American Economic Review, v. 46, no. 5, p. 894-908, 1956.

Disponível em: www.jstor.org/stable/1811910. Acesso em: 12 fev. 2020 
OLIVEIRA, Francisco. Elegia para uma Re(li)gião: Sudene, Nordeste.

Planejamento e Conflito de Classes. 4. ed. Rio de Janeiro: Paz e Terra, 1981. 132 p.

PACHECO, Carlos Américo. Desconcentração econômica e fragmentação da economia nacional. Economia e Sociedade, Campinas, (6): 113-40, jun., 1996.

PEREIRA, William Eufrásio Nunes. 0 desenvolvimento econômico e a redução das desigualdades regionais enquanto princípios constitucionais desrespeitados por políticas incentivadoras da guerra fiscal. 2018. $96 \mathrm{f}$. Monografia (Graduação) - Curso de Direito, Universidade Federal do Rio Grande do Norte, Natal, 2018.

PRADO JÚNIOR, Caio. Formação do Brasil Contemporâneo-Colônia. 7ed. São Paulo: Brasiliense, 1963

RAFFESTIN, Claude. Por uma Geografia do Poder. São Paulo: Ática, 1993. 136 p.

RAMMÊ, Rogério Santos. O federalismo em perspectiva comparada: contribuições para uma adequada compreensão do federalismo brasileiro. Revista Eletrônica Direito e Política, Programa de Pós-Graduação Stricto Sensu em Ciência Jurídica da UNIVALI, Itajaí, v.10, n.4, 3ํquadrimestre de 2015. Disponível em: www.univali.br/direitoepolitica. Acesso em: 10 ago. 2020.

SILVA, Caio Cezar Fernandes. Evolução do Emprego Formal do Rio Grande do Norte no Novo Milênio. 2019. 82f. Monografia (Graduação) - Ciências Econômicas, Universidade Federal do Rio Grande do Norte, Natal, 2019.

http://dx.doi.org/10.13140/RG.2.2.34350.33609

SILVA, Marconi Gomes. Mercado de trabalho, ocupações e rendimentos: a Região Metropolitana de Natal na década de 1990. 2008. 297 f. Tese (Doutorado em Desenvolvimento Regional; Cultura e Representações) - Universidade Federal do Rio Grande do Norte, Natal, 2008.

TINOCO, Guilherme. A sustentabilidade fiscal dos estados brasileiros: análise recente e notas para o futuro. Revista BNDES, Rio de Janeiro, v. 25, n. 50, p. 299344, dez. 2018.

TRINDADE, Sérgio Luiz Bezerra. História do Rio Grande do Norte. Natal: Editora do IFRN, 2010. $281 \mathrm{p}$.

TROVÃO, Cassiano José Bezerra Marques; ARAÚJO, Juliana Bacelar.

Desenvolvimento e mercado de trabalho em tempos de Covid-19: os impactos dos auxílios emergenciais na Região Metropolitana de Natal e no Rio Grande do Norte. In: CLEMENTINO, Maria do Livramento Miranda; ALMEIDA, Lindijane de Souza Bento; SILVA, Brunno Costa do Nascimento (org.). Em tempos de pandemia: contribuições do Observatório das Metrópoles: núcleo Natal. Rio de Janeiro: Letra Capital, 2020. Cap. 12. p. 201-224. 